УДК: 311.312

JEL Classifications: C 15

О. Г. ОСАУЛЕНКО,

доктор наук з державного управління, професор, член-кореспондент НАН Украӥни, заслужений економіст України,

ректор,

Національна академія статистики, обліку та аудиту

\title{
Координація національної статистичної системи в контексті інформаційної безпеки
}

В статті обтрунтовано необхідність побудови в краӥні національної статистичноі системи (НСС) для забезпечення координації статистичних робіт. На основі системного підходу надано визначення НСС, розкрито передумови створення і розвитку НСС, підкреслено роль державної політики координації в організації статистичної діяльності в межах НСС, наведено основні задачі єдиної начіональної політики $з$ координації статистичної діяльності. Висвітлено різні аспекти функиіонування НСС, обтрунтовано необхідність створення Національної статистичної комісії.

Ключові слова: інформаційна безпека, статистика, національна статистична система, координація.

Ефективне управління офіційними інформаційними потоками в країні можливе за умови їх координації на національному рівні. Це дозволяє не лише оптимізувати часові, фінансові та людські витрати інформаційного виробничого процесу, але й суттєво підвищити глобальну якість інформації, передусім у контексті національної інформаційної безпеки.

У сфері статистики така координація високого рівня забезпечується шляхом створення в країні національної статистичної системи (далі - НСС), що стало провідною світовою тенденцією розвитку сучасної офіційної статистики. Статистична комісія Організації Об'єднаних Націй всіляко сприяє і підтримує ініціативи з формування засад НСС та їх імплементації [1].

Загалом місце та функції національної статистичної системи визначаються, передусім, самим її змістом (сутністю) як міжвідомчого утворення. Відповідно до цього постають, перш за все, запитання щодо юридичної бази НСС, покладених на неї повноважень, системи керівництва та фінансових джерел діяльності.

Сам термін «статистична система» виник у зв'язку з сучасними світовими реаліями в офіційній статистичній практиці, пов'язаними з тим фактом, що не існує жодної країни у світі, де б одна-єдина установа була повністю відповідальною за збирання та продукування статистичної інформації на національному рівні. За будь-яких економічних, адміністративних та юридичних умов офіційна статистика завжди представлена більшою чи меншою групою інституцій, задіяних у розробці статистичних даних. Принагідно слід зазначити, що наявність власне системи не обов'язково витікає 3 факту існування вказаної групи інституцій. Очевидно, що будь-яка реальна система має організацію, але не всяка організація виступає як система [2]. По-перше, історично інституції-виробники тієї чи іншої статистичної інформації у будь-якій країні можуть створюватись і функціонувати незалежно одна від одної. По-друге, статистичний аспект їх діяльності може переслідувати не обов'язково національні, а швидше галузеві та відомчі інтереси. Ці два моменти породжують «несистемність» у національній статистичній діяльності через відсутність їі загальних юридичних, методологічних та організаційних засад. Як результат, у багатьох країнах, де НСС наразі не створена, на фоні відсутності єдиної державної політики в галузі інформації і статистики можна спостерігати неузгодженість і дублювання статистичної діяльності різними задіяними установами, невиправдано високе навантаження на респондентів за недостатнього рівня задоволення потреб споживачів інформації, високу витратність формування

(C) О. Г. Осауленко, 2017

НАУКОВИЙ ВІСНИК НАЦІОНАЛЬНОÏ АКАДЕМІї 


\section{СТАТИСТИКА}

кінцевого інформаційного продукту й, відповідно, його низьку якість, тобто загалом незадовільний рівень глобальної якості статистичної інформації.

Небезпечним наслідком відсутності НСС є також неможливість реалізації узгодженого управління безпекою статистичної інформації, а саме, унеможливлення навмисного викривлення інформації, забезпечення дотримання правил щодо конфіденційності даних та роботи $з$ даними, що становлять державну таємницю.

Усвідомлення потреби у застосуванні системного підходу до організації статистичної практики відбувається як на міжнародному, так і на національному рівнях та безпосередньо пов'язане з потребами підвищення ефективності процесу прийняття рішень на усіх рівнях управління, у тому числі й з питань інформаційної безпеки. Тривалий час це питання залишалося поза увагою вищого керівництва статистичних служб країн та їх урядів. Слід також ураховувати, що значна кількість принципів системної побудови національної статистики була розроблена й, відповідно, випливає з умов економічно і статистично розвинених країн, таких як Австралія, Канада, Німеччина, Франція, Сполучені Штати Америки, які функціонують в умовах сталості економіки та суспільства. Формування НСС в умовах країн з несталими економічною та політичною ситуаціями часто потребує пошуку, крім загальноприйнятих, також альтернативних підходів до практичної реалізації цього складного завдання.

3 огляду на вищевикладене, національну статистичну систему можна визначити як складне утворення, безпосередньо пов'язане з системою виконавчої влади країни і діюче відповідно до національного законодавства в галузі статистики та міжнародних статистичних стандартів, головна функція якого полягає в оптимізації процесу виробництва суспільно важливої інформації для збалансування вартості кінцевого статистичного продукту зі стандартами глобальної якості статистичної діяльності 3 метою максимального забезпечення суспільного попиту на статистичну інформацію.

Важливою передумовою створення і розвитку національної статистичної системи є стратегічне планування цього процесу; безпосередній трансформації НСС має передувати розробка і затвердження Національних стратегій розвитку статистики. Останні як елементи загального інформаційного простору країни повинні безпосередньо узгоджуватись із державною політикою у сфері інформації і, в тому числі, у сфері безпеки інформації.

Незважаючи на те, що створення та розвиток будь-якої НСС має спиратися на загально визнані на міжнародному рівні підходи (згідно 3 досвідом різних країн, передусім статистично розвинених), ці підходи можуть і повинні враховувати також специфічні для кожної конкретної країни умови, пов'язані з адміністративним устроєм, історичними передумовами, системою законодавчої та виконавчої влади, структурою економіки, системою управління інформацією та системою безпеки.

Національна статистична система, незалежно від типу організації (перш за все, централізованої чи децентралізованої), завжди є складним організмом, окремі функції якого реалізуються у різних інституціях та на різних ієрархічних щаблях. За таких умов видається дуже складним завдання утримання однорідності й узгодженості у статистичній діяльності між іiї різними учасниками з метою запобігання дублюванню процесів та продуктів, а значить, і витрат, та виникненню ризику втрат якості. Саме тому єдина державна політика координування має бути тим інструментом, який дозволяє організувати статистичну діяльність всієї НСС на базі єдиних методологічних засад і статистичних стандартів та в межах загальної системи інформаційної безпеки країни.

Для уникнення конфлікту інтересів функція координації повинна бути закріплена законодавчо й покладена на організацію, відносно незалежну від керівників відповідних міністерств і відомств. Основними завданнями єдиної національної політики 3 координації статистичної діяльності мають бути [1]:

1. планування фундаментальних напрямів удосконалення та розвитку НСС;

2. контроль плану статистичних спостережень з метою його узгодження між учасниками системи, а також між виробниками та споживачами статистичного продукту і подальше його затвердження;

3. встановлення і планомірне впровадження системи статистичних стандартів;

4. загальна координація статистичної діяльності в країні; 
5. планування програм з підвищення кваліфікації в галузі статистики та управління підвищенням рівня підготовки статистичного персоналу;

6. координування міжнародної діяльності в галузі статистики;

7. здійснення специфічних (крім тих, що покладаються на конкретних учасників системи) заходів з розвитку та вдосконалення статистики.

3 огляду на міжнародний досвід, на сучасному етапі розвитку, окрім вищезазначених традиційних складових, координація діяльності НСС у контексті інформаційної безпеки потребує врахування таких вимог:

1. забезпечення системного розвитку офіційної статистики;

2. поширення й регламентація доступу та забезпечення ефективного використання статистичних даних;

3. посилення забезпечення конфіденційності та захисту індивідуальних даних;

4. створення міжвідомчих механізмів контролю та захисту секретної статистичної інформації;

5. організація системи статистичних спостережень 3 питань інформаційної безпеки країни;

6. створення національної статистичної комісії.

Забезпечення системного розвитку офіційної статистики передбачає охоплення статистичним плануванням не лише прямих виробників статистичного продукту на підставі статистичних обстежень та переписів, а й виробників адміністративних даних, які можуть бути використані для продукування кінцевої статистичного інформації 3 безумовним урахуванням інтересів ії основних споживачів. 3 цією метою застосовуються такі інструменти управління національною статистичною системою, як мастер-план (Master Plan), ключові статистичні дані та інформація (Fundamental Statistics) та інші.

Так званий мастер-план є сучасним інструментом планування, що дозволяє розвивати офіційну статистику у систематичний, а також зрозумілий і прозорий для всіх учасників процесу спосіб та $є$ широко уживаним у НСС розвинених країн.

Побудова та реалізація мастер-плану має спиратися на такий фундаментальний аспект національної політики в галузі статистики, як безумовне визнання та підвищення сучасної ролі офіційної статистики у суспільстві. Це означає наявність двох зустрічних потоків зусиль: з боку як держави й суспільства, так і самих виробників статистичної інформації. Суспільство повинно усвідомлювати необхідність розвитку статистики як важливого джерела інформації, яка є основою прийняття суспільно корисних рішень на всіх рівнях управління. А статистики, у свою чергу, повинні забезпечити максимально можливе залучення суспільства до формування суспільно корисної статистичної інформації, починаючи з вивчення потреб користувачів і закінчуючи поширенням кінцевого продукту.

Ключові статистичні дані окреслюють найбільш важливу, пріоритетну для споживачів інформацію, створювану як на підставі статистичних обстежень і переписів, так і з використанням адміністративних даних, яка продукується на регулярній основі в межах мастер-плану. Ключові статистичні дані $є$ серцевиною всієї агрегованої статистичної інформації.

Поширення йрегламентаџія доступу та ефективне використання статистичних даних вимагає, поміж іншим, встановлення законодавчо закріплених правил надання інформації користувачам, передусім агрегації даних за індивідуальними, специфічними замовленнями, а також надання знеособлених індивідуальних (персональних) даних для різного роду наукових досліджень.

Посилення забезпечення конфіденційності та захисту індивідуальних даних передбачає наявність системи покарань за використання або надання інформації, отриманої у ході статистичних спостережень, для нестатистичних цілей, а також за порушення положень щодо конфіденційності індивідуальних даних. Оскільки ці положення є загальновживаними, то вони мають застосовуватись як до державних службовців, так і до приватних підрядників, що виконують роботи на замовлення для потреб НСС.

Міжнародний досвід зі створення міжвідомчих механізмів контролю та захисту секретної статистичної інформації свідчить про ефективність поєднання й 


\section{СТАТИСТИКА}

узгодження національних юридичних норм у цій сфері з міжнародними. Це створює скоординований механізм захисту секретної інформації, яка обертається у сфері офіційної статистики, не лише на рівні окремих відомств та на міжвідомчому рівні, але й на міжнародному (наприклад, на рівні $\mathrm{CC}$ ). Слід зазначити, що нормативноправове поле щодо роботи з секретною інформацією у сфері офіційної статистики не $\epsilon$ раз і назавжди сформульованим. Так само, як і вся НСС, воно є відкритою системою у стані постійної еволюції і переглядається й актуалізується відповідно до сучасних потреб інформаційної безпеки. На підставі відповідних законів розробляються стандарти поводження із секретною інформацією та рекомендації з їх упровадження у практичну статистичну діяльність, які теж постійно оновлюються відповідно до змін у законодавстві [3].

Організація системи статистичних спостережень з питань інформаційної безпеки краӥни. До недавнього часу сфера таких обстежень залишалась прерогативою приватних компаній та дослідницьких академічних установ. Опитувалися при цьому переважно підприємства та керівники або фахівці з інформатики. Безліч зацікавлених компаній та організацій продовжують і зараз продукувати й поширювати відповідну статистику. Коді Корнелл, один із фундаторів американської компанії Б^ітіапе, завданням якої є посилення здатності підприємств та урядових структур забезпечувати власну інформаційну безпеку [4], узагальнив і опублікував (із позначенням джерел) у 2016 році десять ключових статистичних фактів щодо інформаційної безпеки, які одночасно підкреслюють як вагомість самої проблематики, так і значні виклики для суспільства у цій сфері:

1. Понад 169 мільйонів персональних записів у 2015 році зазнали небезпеки через виток інформації із 781 джерел фінансового, ділового, освітянського, урядового та медичного секторів.

2. Середня загальна вартість кожного втраченого, пошкодженого чи викраденого запису, який містить конфіденційну та чутливу інформацію, склала 154 долари США. Найвитратнішим у цьому плані є сектор охорони здоров'я, де середня вартість одного пошкодженого запису склала 363 долари США.

3. Кількість випадків інформаційних атак у 2015 році зросла на $38 \%$ порівняно 3 попереднім роком.

4. Разом 3 тим, незважаючи на очевидну загрозу, лише $29 \%$ підприємств малого та середнього бізнесу у 2015 році, що навіть менше за попередній рік (39\%), використовували стандартні засоби упередження витоку інформації.

5. Середній період, упродовж якого хакери діють непоміченими (сплячими) у мережі до моменту їх виявлення, складає понад 200 днів.

6. Щонайменше $52 \%$ респондентів відчули, що впродовж року мали місце потужні кібератаки в мережах, в яких вони зареєстровані.

7. Близко 70\% кібератак використовують комбінацію так званих тактик «фішінгу» та «хакінгу», а також уражують не лише безпосередніх жертв, а й опосередкованих.

8. Близько 74\% керівників служб інформаційної безпеки мали справу з викраденням персональних даних щодо працівників організацій, установ чи компаній.

9. Лише 38\% глобальних організацій впевнені, що вони дійсно готові до захисту проти кібератак підвищеного рівня складності.

10. Понад $81 \%$ опитаних жертв витоку даних заявили, що ані система, ані служба з управління безпекою не $є$ самодостатніми з позиції можливості виявлення інформаційного витоку. Натомість вони є залежними від третіх (зовнішніх щодо організації чи компанії) осіб. I це незважаючи на загальновідомий факт, згідно з яким внутрішнє виявлення витоків займає в середньому 14,5 днів, тоді як зовнішнє сягає в середньому 154 дні.

Оскільки завданнями офіційної статистики є інформування суспільства щодо значущих питань соціального, економічного та політичного розвитку, то феномен національної інформаційної безпеки, який є новим явищем, безумовно має спостерігатися, аналізуватися й управлятися державою на підставі даних відповідних статистичних спостережень. Узагальнена інформація, у свою чергу, повинна бути доступною для громадськості. Водночас варто зазначити, що на сьогодні в жодній країні 
ще не створено такого єдиного офіційного статистичного джерела, яке надавало б якісні дані щодо питань національної інформаційної безпеки.

Але у 2013 році Свростатом започатковане річне спеціальне обстеження щодо інформаційної (кібер) безпеки у 28 країнах-членах Європейського Союзу. Одиницею статистичного спостереження обрано окремого мешканця країн ЄС. Це обстеження має на меті висвітлити інтенсивність та спосіб використання населенням Інтернету i відповідних найбільш популярних технічних пристроїв (гаджетів), а також у яких видах щоденної активності люди сьогодні найбільше використовують Інтернет. Основним питанням при цьому є реакція населення на зростання інформаційної небезпеки при використанні Інтернету, а саме досліджується, чи схильні різні соціальні та вікові групи населення міняти поведінку своєї он-лайн активності з урахуванням зростаючих загроз. 3'ясовується також, наскільки добре населення поінформоване щодо існуючих ризиків використання Інтернету та чи зазнало воно шкоди від цього. Якщо так, то якої саме, як часто та які форми захисту використовувалися до вказаних атак і після них. Особливу важливість становить рубрика із запитаннями щодо методів захисту дітей у сім'ях від існуючих Інтернет-загроз [5].

Національна статистична комісія (НСК) має бути незалежним органом, що створюється для аналізу та прийняття зважених рішень на підставі колективної експертизи. Вона зазвичай складається з досвідчених та визнаних у галузі статистики експертів. НСК відіграє центральну роль у системному вдосконаленні офіційної статистики з метою підвищення глобальної якості статистичної інформації за рахунок безпосередньої участі в обговоренні життєво важливих напрямів їі розвитку, складових мастер-плану та ключових статистичних даних, а також надаючи рекомендації відповідним міністерствам та відомствам. Ця комісія повинна також відігравати провідну роль у координації зусиль щодо узгодження статистичної діяльності з вимогами національної інформаційної безпеки, що досягається шляхом введення до їі складу експертів із інформатики та безпеки.

Слід зазначити, що упровадження систем управління глобальною якістю, тобто не лише якістю статистичних даних, але і якістю поводження з інформацією у процесі її виробництва, оприлюднення й використання, ще не набуло достатнього поширення в національних статистичних системах, за винятком розвинених країн. Підходи, незважаючи на розроблені міжнародні стандарти, різняться від країни до країни. Слабкою ланкою залишаються питання інформаційної безпеки, оскільки їі забезпечення на базі впровадження стандартів якості потребує скоординованих зусиль не тільки в межах НCC, але й інших урядових структур з відповідним колом компетенцій [6]. Висока актуальність і перспективність указаної проблематики, а також ії новизна та відсутність достатнього досвіду потребують детального дослідження й удосконалення підходів 3 подальшою їх апробацією на національному і на міжнародному рівнях.

\section{Список використаних джерел}

1. Осауленко О. Г. Національна статистична система: стратегічне планування, методологія та організація: монографія. Київ: ДП «Інформ.-аналіт. агентство», 2008. 415 c.

2. Урсул А. Д. Проблема информации в современной науке. Философские очерки. Москва: Наука, 1975. 286 с.

3. Guide du secret statistique / INSEE. Dernière mise à jour: 18 octobre 2010. URL: https:// www.insee.fr/fr/statistiques/fichier/1300624/guide-secret.pdf

4. Empowering organizations with streamlined security operations / Swimlane. URL: https:// swimlane.com/about/

5. Cyber Security. Report / Special Eurobarometer 423. Wave EB82.2 - TNS Opinion \& Social. URL: http://ec.europa.eu/commfrontoffice/publicopinion/archives/ebs/ebs_423_ en.pdf

6. Осауленко О. Г. Офіційна статистика у системі національної інформаційної безпеки / О. Г. Осауленко // Порівняльні статистичні дослідження розвитку соціальноекономічних систем: мат. XV Міжнар. наук.-практ. конф. з нагоди Дня працівників статистики, м. Київ, 05 грудня 2017 р. Київ: ДП «Інформ.-аналіт. агентство», 2017. C. $16-21$. 

заслуженный экономист Украинь, ректор,

Наџиональная академия статистики, учета и аудита

\section{Координация национальной статистической системы в контексте информационной безопасности}

В статье обоснована необходимость построения в стране национальной статистической системы (НСС) для обеспечения координации статистических работ. На основе системного подхода дано определение НСС, раскрыты предпосылки создания и развития НСС, подчеркнута роль государственной политики координации в организации статистической деятельности в рамках НСС, приведень основные задачи единой национальной политики координаџии статистической деятельности. Освещеныразные аспекты функциионирования НСС, обоснована необходимость создания Национальной статистической комиссии.

Ключевые слова: национальная статистическая система, информационная безопасность, статистика, координация.

O. H. OSAULENKO,

Dsc (Public Administration), Professor, Corresponding Member of the NAS of Ukraine, Honored Economist of Ukraine, Rector,

National Academy of Statistics, Accounting and Audit

\section{Coordination of the National Statistical System in the Information Security Context}

The needfor building the national statistical system (NSS) as the frameworkfor coordination of statistical works is substantiated. NSS is defined on the basis of system approach. It is emphasized that the essential conditions underlying NSS are strategic planning, reliance on internationally adopted methods and due consideration to country-specific environment. The role of the state coordination policy in organizing statistical activities in the NSS framework is highlighted, key objectives of the integrated national policy on coordination of statistical activities are given. Threats arising from non-existence of NSS in a country are shown: "irregular" pattern of statistical activities, resulting from absence of common legal, methodological and organizational grounds; high costs involved in the finished information product in parallel with its low quality; impossibility of administering the statistical information security in a coherent manner, $i$. e. keeping with the rules on confidentiality of data, preventing intentional distortion of information and keeping with the rules of treatment with data making the state secret. An extensive review of NSS functional objectives is made: to ensure the system development of the official statistics; to ensure confidentiality and protection of individual data; to establish interdepartmental mechanisms for control and protection of secret statistical information; to broaden and regulate the access to statistical data and their effective use. The need for creating the National Statistical Commission is grounded.

Keywords: national statistical system, information security, statistics, coordination.

\section{Посилання на статтю:}

Осауленко О. Г. Координація національної статистичної системи в контексті інформаційної безпеки // Науковий вісник Національної академії статистики, обліку та аудиту: зб. наук. пр.. 2017. №4. С. 7-12. 